\title{
Utilization of disperse metalworking wastes in the building ceramic production
}

\author{
Natalia Skanavi ${ }^{1 *}$ \\ ${ }^{1}$ Moscow State University of Civil Engineering, Yaroslavskoe shosse, 26, Moscow, Russia, 129337
}

\begin{abstract}
This work is aimed at studying of possibility to use disperse metalwork wastes for building ceramic products manufacture. We performed the overall study of the composition and properties of the steel waterjet cutting disperse wastes and their behavior as part of the ceramic paste and baked ceramics. We noticed a positive effect of the wastes' additives on the ceramic properties for three types of polymineral clay raw materials: reduction of air and fire shrinkage, strength improvement at optimal wastes content in the mixture, possibility to get quality baked ceramics at $900-950^{\circ} \mathrm{C}$, improvement of the material hydro physical properties and possibility to vary the products' colors. The received results allowed us to make a conclusion about possibility to use the steel waterjet cutting disperse wastes in the building ceramic production as a polyfunctional component: effective thinning agent, fluxing agent and component for volume coloring.
\end{abstract}

\section{Introduction}

Accumulation of large quantity of the production and human activity wastes is a serious ecological problem for big cities. The amount of the accumulated wastes in the Russian Federation exceeds 50 billion tons, and this figure increases annually. In 2017 the amount of the accumulated wastes was equal to 6220.6 million tons. The amount of the annually accumulated wastes increased by $66.5 \%$ from 2010 to 2017 [1]. Waste dumps and disposal sites occupy giant areas. The wastes of numerous manufacturing industries, considered nonhazardous safe, are disposed in the solid domestic waste landfills, increasing the already significant environmental burden. Any major urban agglomeration shall solve in first turn the issues of wastes separate collection, their transportation, storage and maximum utilization.

Disperse wastes generated during mechanical processing of ferrous and non-ferrous metals, relate to the waste category, which is almost not studied with regard to utilization in the building materials production. They include the wastes, generated during metals processing with cutting, turning, milling, drilling, chiseling, grinding etc. At the same time

\footnotetext{
*Corresponding author: a_skanavi@postman.ru
} 
these wastes are so diverse, they are generated in sufficient quantities and their composition allows to consider some of them as a possible component of the raw building mixes.

This work studied the steel waterjet cutting wastes. In accordance with FCCW 2019 they relate to 5 hazard class, i.e. non-hazardous (FCCW code - 36121872395 - sand wastes during the waterjet cutting of ferrous and non-ferrous metals are almost nonhazardous) [2]. Hazard class 5 wastes do not require a passport system; they almost do not affect the environment and do not require special terms of transportation and storage.

We should note that the other disperse metalwork wastes relate to 4 hazard class, i.e. to less hazardous, that is caused by the fact that some of them contain refined products, oils and other causes.

\section{Objects and study methods}

\subsection{Wastes generating mechanism during the waterjet cutting}

A favorable characteristic of the waterjet cutting wastes relates to the peculiarities of this type of cutting. The core of the process is in the action on the material with high speed $(300 \div 900 \mathrm{~m} / \mathrm{s})$ water jet, mixed with abrasive [3]. When the jet collided with the material, its kinetic energy converts into mechanical energy of the material microlysis and cutting occurs.

Garnet sand is used as abrasive [4,5], it mainly consists of iron aluminium garnet almandine $\left(\mathrm{Fe}_{3} \mathrm{Al}_{2}\left[\mathrm{SiO}_{4}\right]_{3}\right)$. This mineral is cherry red, it has high hardness $-7 \div 8$ according to Mohs scale, high density $-4.1 \div 4.3 \mathrm{~g} / \mathrm{cm}^{3}$, very high damage tolerance, and is characterized by lack of toxicity in related to human and environment.

At present it is the waterjet cutting, that is one of the most effective methods of sheet metal cutting. In comparison with the other cutting types this technology does not have a thermal effect on metal; you can cut fabricated materials of big thickness (above $300 \mathrm{~mm}$ ) as well as pile of several sheet layers, the process is characterized by small cut width $(0.2 \div 3$ $\mathrm{mm}$ ) and high quality of the finished surface and ecological compatibility due to lack of inflammable and explosive materials. These advantages allow us to consider that a share of the waterjet cutting in the metal cutting sphere will grow; therefore, the number of the generated wastes will increase as well.

As a result of the waterjet cutting process you get the wastes in the form of slurry, containing the garnet abrasive, destroyed during cutting, cut metal particles and water. Dehydrated remainder is stored at the enterprise and then transported to the solid domestic waste landfills as it accumulates.

\subsection{Characteristic of steel waterjet cutting wastes}

In the course of the overall study of the wastes dry part we received the following results: true density $3.92 \mathrm{~g} / \mathrm{cm}^{3}$, bulk density - $2.157 \mathrm{~g} / \mathrm{cm}^{3}$. Granulometric composition, determined on the standard sieve set according to GOST $8735-88$, is presented mainly by two fractions: fine $(0.16 \div 0.315 \mathrm{~mm}-70.5 \%)$ and finest (below $0.16 \mathrm{~mm}-27.1 \%)$ [6,7]. We found out that the wastes finest fraction includes the cut materials particles. This is proved with the electron microscopic study results, performed on raster electron microscope FEIQUANTA 200 [6,7].

Sieving waste samples on the standard sieves set according to ISO 3310-1 and determining true and bulk density of individual fractions showed that the density values significantly depended on the wastes fraction. The finer the fraction, the higher density value is, that implicitly proves increase of metal content in it. Thus, fraction above $0.25 \mathrm{~mm}$ 
has true density $3.65 \mathrm{~g} / \mathrm{cm}^{3}$, fraction $0.125 \div 0.25 \mathrm{~mm}-4.04 \mathrm{~g} / \mathrm{cm}^{3}$, fraction $0.063 \div 0.125$ $\mathrm{mm}-4.074 \mathrm{~g} / \mathrm{cm}^{3}$, and fraction below $0.063 \mathrm{~mm}-4.47 \mathrm{~g} / \mathrm{cm}^{3}$.

The mineral composition of a homogenized waste sample is represented mainly by two garnet group minerals - almandine $\mathrm{Fe}_{3} \mathrm{Al}_{2}\left(\mathrm{SiO}_{4}\right)_{3}-88.9 \%$ and pyrope $\mathrm{Mg}_{3} \mathrm{Al}_{2}\left(\mathrm{SiO}_{4}\right)_{3}$ $6.8 \%$. The remaining $4.3 \%$ is accounted for ilmenite $\mathrm{FeTiO}_{3}-2.8 \%$ and quartz $\mathrm{SiO}_{2}-1.5 \%$. Three basic oxides prevail in the chemical composition: $\mathrm{Fe}_{2} \mathrm{O}_{3}-35.07 \%$; $\mathrm{SiO}_{2}-31.02 \%$; $\mathrm{Al}_{2} \mathrm{O}_{3}-17.22 \%$. $\mathrm{TiO}_{2}-7.62 \%$ and $\mathrm{MgO}-6.74 \%$ present in noticeable amounts.

Therefore, in the course of the overall study of the waterjet cutting wastes we found that they represent very fine almost two-fractions heavy sands with high content of the dust fraction, the chemical composition of which consists mainly from iron, silicon and aluminum oxides. Such wastes characteristic allowed us to specify possible ways of their utilization, one of which is production of wall building ceramic $[6,7]$.

\subsection{Clay raw materials for ceramic material production with steel waterjet cutting wastes}

In the work we studied and used three kinds of clay raw materials:

a) from Novopodrezkovo production field with a technological line of OJSC "Losinoostrovsk construction materials and structures works" (Clay 1). The main components of the mineral composition: quartz - $49 \%$ and montmorillonite $-25 \%$. There is a significant amount of hydromica - 7\%, microcline - 5\%, kaolinite - 3\%, hematite $-3 \%$ and amorphous phase $-8 \%$. $\mathrm{SiO}_{2}-65.08 \%, \mathrm{Al}_{2} \mathrm{O}_{3}-14.85 \%, \mathrm{Fe}_{2} \mathrm{O}_{3}-11.65 \%$ prevail in the chemical composition [5].

b) from Golitsyno production field with a technological line of PJSC "Golitsynsk Ceramic Works" (Clay 2). The clay rock is "sandy" and poor in clay-forming minerals. The mineral composition is mainly presented by quartz $-54.2 \%$, a small part consists of field spars: microcline $-10.7 \%$ and albite $-8.4 \%$; clay minerals are represented by halloysite only $-11.9 \%$, and $10 \%$ present in the amorphous phase. The following oxides prevail in the chemical composition: $\mathrm{SiO}_{2}-69.99 \%, \mathrm{Al}_{2} \mathrm{O}_{3}-16.14 \%, \mathrm{Fe}_{2} \mathrm{O}_{3}-5.36 \%$.

c) from Gzhel production field with a technological line of LLC "Ceramic Laboratory" - quality high disperse clay raw materials with high content of clay minerals- above $50 \%$ of kaolinite and other clay minerals, with quartz impurities, carbonate rocks and pyrite (iron oxides content is $8 \div 12 \%$ ).

According to their plasticity all three clays belong to the group of moderate plastic clays and according to sensitivity clay 1 and 2 are characterized as highly sensitive clay raw materials and clay 3 as medium sensitive. According to the temperature and caking index the raw material belongs to the group of medium temperature caking.

We tested the raw materials according to GOST 21216-2014 "Clay raw material. Test methods" and classified according to GOST 9169-75 "Clay raw materials for ceramic industry. Classification".

\section{Study of composition, structure and properties of ceramic material with metals waterjet cutting wastes}

\subsection{Preliminary study of steel waterjet cutting wastes behavior as part of ceramic material on Clay 1}

The peculiarity of the steel waterjet cutting wastes as additive to clay raw material is a metallic component, which behavior during burning was to study. We prepared samplecubes with $5 \mathrm{~cm}$ rib, consisting of 50\% Clay 1 and $50 \%$ wastes (by weight) with water solid 
ratio $18 \%$. The samples were dried at $105^{\circ} \mathrm{C}$ and then burnt at $900^{\circ} \mathrm{C}$. The samples did not deform, crack or change the color during burning. The metallic component did not become visible. The burnt material had the following physical mechanical characteristics: average density - $2.4 \mathrm{~g} / \mathrm{cm}^{3}$, water absorption- $11.6 \%$, compression resistance - $13.47 \mathrm{MPa}$. Samples' color is red. We can explain true density high value by garnet abrasive high density and presence of metallic component.

There are no primary clay minerals (montmorillonite and others), underwent known temperature changes in the ceramic fragment mineral composition. We identified almandine (13.5\%) and hematite (13.2) from the wastes. Thus, we can say that the burning temperature $900^{\circ} \mathrm{C}$ is sufficient for clay minerals transformation, but it is not sufficient for almandine phase transformations. We have the data that almandine decays at the temperature above $900^{\circ} \mathrm{C}$, generating a ferromagnetic king of hercynites, glandular cordierite and fayalite [4].

The preliminary study allowed us to make a conclusion that it was possible to use the steel waterjet cutting wastes for ceramic goods production.

\subsection{Clay 2 samples production and test}

In order to test the waterjet cutting wastes behavior at the temperature above possible almandine decay on Clay 2 we prepared the sample-cubes with $4 \mathrm{~cm}$ ribs, made of raw mixtures with different composition. Raw mixtures composition, \% by weight (Clay 2: wastes): $20: 80,40: 60,65: 35$ and 100:0. The water solid ratio for all the mixtures with wastes was $18 \%$. The samples were dried and burnt at $950{ }^{\circ} \mathrm{C}$.

The samples did not deform and crack after burning. The samples color changed from light red in the composition without wastes to dark red-brown with maximum wastes content in the mixture, that is associated with a high content of coloring iron oxides in the wastes. Table 1 shows the sample physical mechanical properties.

Table 1. Physical and mechanical properties of Clay 2 ceramic samples

\begin{tabular}{|c|c|c|c|c|c|c|}
$\begin{array}{c}\text { Wastes } \\
\text { content by } \\
\text { weight, } \%\end{array}$ & $\begin{array}{c}\text { Average } \\
\text { density, } \\
\mathrm{g} / \mathrm{cm}^{3}\end{array}$ & $\begin{array}{c}\text { True } \\
\text { density, } \\
\mathrm{g} / \mathrm{cm}^{3}\end{array}$ & $\begin{array}{c}\text { Porosity, } \\
\%\end{array}$ & $\begin{array}{c}\text { Air } \\
\text { shrinkage, } \\
\%\end{array}$ & $\begin{array}{c}\text { Fire } \\
\text { shrinkag } \\
\mathrm{e}, \%\end{array}$ & $\begin{array}{c}\text { Compression } \\
\text { resistance, } \\
\mathrm{MPa}\end{array}$ \\
\hline 0 & 1,79 & 2,68 & 33,07 & 12 & $-1,07$ & 10,69 \\
\hline 35 & 2,08 & 3,05 & 31,79 & 5 & $-1,9$ & 16,36 \\
60 & 2,17 & 3,35 & 35,28 & 4,58 & $-2,79$ & 10,29 \\
\hline 80 & 2,26 & 3,53 & 36,04 & 2,83 & $-3,23$ & 8,47 \\
\hline
\end{tabular}

As the amount of the wastes content in the mixture increases, average and true samples' density grows as well, it is caused by high density of the wastes themselves. We observed significant reduction of air and fire shrinkage. Thus, if the wastes content in the mixture is $35 \%$, the air shrinkage decreases by 2.4 times, and the fire one - by 1.8 times. If the wastes content in the mixture is $80 \%$, the air shrinkage decreases by 4.2 times and the fire one - by 3 times. Therefore, adding of the waterjet cutting wastes at the stage of drying and burning in any amount restrains the volume changes and acts as an effective thinning additive.

Wastes introduction in the amount of $60 \%$ almost does not affect the samples' strength. The optimal variant in terms of strength is $35 \%$ wastes content, strength gain is above $50 \%$. This mixture was also characterized by minimum porosity. 
In the course of determination of the baked ceramics composition we found out that the wastes samples contained unchanged almandine. It proves that burning temperature $950^{\circ} \mathrm{C}$ for these compositions and conditions was not sufficient for temperature almandine changes. However, considering the good indicators of the physical-mechanical properties and the results of the electronic microscopic study [6,7], showing good quality of the ceramic fragment, it is unreasonable to increase the temperature.

The received results coincide with the available data about influence of the iron-ore containing additives, which include the steel waterjet cutting wastes, on the ceramic's properties. Introducing of the iron-ore containing additives in the ceramic paste composition as metal ware production wastes and waste sludge portion of the iron ore dressing [8] increases the ceramic material strength from 12 to $20 \mathrm{MPa}$ due to more active caking of the ceramic pastes and increase of the liquid phase during burning. It means that iron-ore containing additives act as a fluxing agent. The optimal burning temperature was $950{ }^{\circ} \mathrm{C}$ and the metal ware production wastes - dark red disperse powder, consisting of hematite $\mathrm{Fe}_{2} \mathrm{O}_{3}$ - was studied as a coloring pigment for ceramic goods.

\subsection{Clay 3 samples production and test}

In order to study the influence of the waterjet cutting wastes on the raw mixtures' plasticity, we prepared the mixtures with different ratio of the clay component and wastes. Raw mixtures compositions, \% by weight (Clay 3: wastes): 100:0, 90:10, 80:20, 70:30, 60:40 and 50:50. We selected the water solid ratio so that to ensure equal mixtures' consistency, corresponding to moderately plastic state of the clay paste. We determined consistency dipping the balancing cone in the mixture. Penetration depth was $14 \mathrm{~mm}$. Table 2 shows the received results. We determined that the higher the wastes content in the raw mixture, the lower the water solid ration was.

We prepared the sample-cubes with $4 \mathrm{~cm}$ rib out of the equal consistency mixtures. The samples were dried and burnt at $950^{\circ} \mathrm{C}$.

Table 2. Physical and mechanical properties of Clay 3 ceramic samples

\begin{tabular}{|c|c|c|c|c|c|c|}
$\begin{array}{c}\text { Wastes } \\
\text { content by } \\
\text { weight, } \%\end{array}$ & $\begin{array}{c}\text { Average } \\
\text { density, } \\
\mathrm{g} / \mathrm{cm}^{3}\end{array}$ & $\begin{array}{c}\text { True } \\
\text { density, } \\
\mathrm{g} / \mathrm{cm}^{3}\end{array}$ & $\begin{array}{c}\text { Air } \\
\text { shrinkage, } \\
\%\end{array}$ & $\begin{array}{c}\text { Fire } \\
\text { shrinkage, } \\
\%\end{array}$ & $\begin{array}{c}\text { Total } \\
\text { shrinkage, } \\
\%\end{array}$ & $\begin{array}{c}\text { Compression } \\
\text { resistance, } \\
\mathrm{MPa}\end{array}$ \\
\hline 0 & 40 & 1,87 & 12 & 2,60 & 14,29 & 48,72 \\
\hline 10 & 32 & 1,98 & 7,44 & 2,53 & 9,78 & 64,16 \\
\hline 20 & 29 & 1,98 & 7,36 & 2,58 & 9,26 & 58,33 \\
\hline 30 & 27 & 1,99 & 6,40 & 0,93 & 7,27 & 50,93 \\
50 & 23 & 2,05 & 5,24 & $-0,14$ & 5,11 & 47,61 \\
\hline 50 & 21 & 2,06 & 4,94 & $-1,24$ & 3,77 & 46,09 \\
\hline
\end{tabular}

As the wastes content in the mixture increases, the air and fire shrinkage significantly decreases, proving the fact that the wastes have a delaying action on the volume changes during drying and burning. Total shrinkage of the mixtures with wastes in comparison with the composition without wastes decreased as follows: by 1.46 times at $10 \%$ wastes content, by 1.97 times at $30 \%$ wastes content and by 3.79 times at $50 \%$ wastes content. 
As in the case with Clay 2 average and true density of the samples with wastes increases and the color of the burnt samples changes from bright red in the mixture without wastes to dark red-brown at maximum wastes content in the mixture.

Samples compression resistance of all mixtures on this quality clay raw materials significantly exceeds the strength requirements for wall ceramic materials and conforms to clinker brick brand M450-M600. If the wastes content in the mixture ranges from 10 to $30 \%$ - the strength of the samples with wastes in comparison with the samples without wastes increases as follows: by $32 \%$ at $10 \%$ wastes content, by 19.7 at $20 \%$ wastes content and by $4.5 \%$ at $30 \%$ content and it decreases insignificantly at $40-50 \%$ content.

If you replace a part of the clay raw materials with the wastes, it will increase water absorption of the ceramic samples and total porosity (Table 3). Thus, when introducing $20 \%$ of wastes the total porosity increases by $19 \%$ and introducing $30 \%$ of wastes - by $30 \%$. Nevertheless, along with this, open porosity share decreases in total porosity, indicating formation of more favorable ceramic fragment structure. So, the pores water saturation coefficient, which serves as indirect frost resistance assessment in all mixtures with the wastes smaller, than in the mixture without wastes, i.e. there is frost resistance positive forecast.

Table 3. Clay 3 samples density and porosity

\begin{tabular}{|c|c|c|c|}
\hline $\begin{array}{c}\text { Wastes content, } \\
\text { by weight } \%\end{array}$ & Open porosity, \% & $\begin{array}{c}\text { Total porosity, } \\
\%\end{array}$ & $\begin{array}{c}\text { Pores water } \\
\text { saturation } \\
\text { coefficient }\end{array}$ \\
\hline 0 & 17,43 & 24,78 & 0,70 \\
\hline 10 & 17,40 & 25,42 & 0,68 \\
\hline 20 & 18,22 & 29,50 & 0,62 \\
\hline 30 & 18,70 & 30,58 & 0,61 \\
\hline 40 & 20,37 & 30,20 & 0,67 \\
\hline 50 & 20,86 & 32,21 & 0,65 \\
\hline
\end{tabular}

We tested the frost resistance of three compositions based on this clay raw materialcontaining $10 \%$ and $20 \%$ wastes, as well as without wastes, through direct freezing and melting. After 50 test cycles the samples did not show any external signs of destruction and weight loss, and the loss of strength did not exceed 3-5\%.

We also determined the strength of those compositions in the water saturated state and evaluated their water resistance. Minimum fluxing coefficient was 0.87 for the mix without wastes.

\section{Conclusion}

We used three kinds of clay raw materials with different composition to show and ground the possibility to use the metals waterjet cutting wastes for building ceramic production. Wastes adding is a polyfunctional active component - it decreases air and fire shrinkage, it increases ceramic material density and strength, it allows to reduce the burning temperature and to get quality baked ceramics at $900-950^{\circ} \mathrm{C}$; it has a favorable effect on its frost and water resistance and provides a possibility to vary the products' color. 
Other disperse metalwork wastes can also be studied in the same way. Oils and refined products in their composition do not prevent from their using in the ceramic production.

According to the forecasts, a share of the building ceramic products in modern construction activity will keep on increasing. Herewith, considering the deficit of the conditioned raw materials, the use of artificial multicomponent mixtures is becoming a tendency, the ratio of natural raw materials in them is very insignificant and the main component is technogenic raw materials- industrial wastes. Therefore, the use of the disperse metal work wastes contribute to extension of the raw materials base for building ceramic production.

\section{References}

1. Scientific-Production Enterprise, 259-269 (2018)

2. FCCW 2019, 242 (2017)

3. Modern material processing technologies Mashinostoyeniye, (2015), ISBN 978-5-94275-793-9

4. A Course of Mineralogy “Applied Geology” (2010), ISBN 978-5-98227-749-7

5. Garnet abrasive. Technical conditions. TU 3988-001-76245879-2011 (2011)

6. N.Skanavi, T. Dovydenko, IOP Conference Series: Materials Science and Engineering. 365.032025 (2018), doi10.1088/1757-899X/365/3/032025.

7. N.Skanavi, T. Dovydenko, MATEC 196, 04057 (2018),

8. Wall ceramic products based on waste coal and iron-ore containing additives 117-128, 129-153 (2011) ISBN 978-5-9902408-8-9. 